\title{
Preservation of liquid whole egg with the combination of heat treatment, high hydrostatic pressure treatment and salt
}

\author{
Karina Ilona HIDAS ${ }^{1}$ - Ildikó Csilla NYULAS-ZEKE² - Adrienn TÓTH ${ }^{3}-$ \\ Csaba NÉMETH ${ }^{4}$ \\ 1: Department of Refrigeration and Livestock Products Technology, Faculty of Food Science, Szent István \\ University, Ménesi Street 43-45., H-1118 Budapest, Hungary, E-mail: hidaskaryna@gmail.com \\ 2: Department of Refrigeration and Livestock Products Technology, Faculty of Food Science, Szent István \\ University, Ménesi Street 43-45., H-1118 Budapest, Hungary, E-mail: Zeke.Ildiko.Csilla@etk.szie.hu \\ 3: Department of Refrigeration and Livestock Products Technology, Faculty of Food Science, Szent István \\ University, Ménesi Street 43-45., H-1118 Budapest, Hungary, E-mail: toth.adrienn@etk.szie.hu \\ 4: Capriovus Ltd., Dunasor 073/72., H-2317 Szigetcsép, Hungary, E-mail: nemeth.csaba@capriovus.hu
}

Keywords: liquid whole egg, shelf life, calorimetric properties, microbiological status, high hydrostatic pressure

\section{Introduction}

Eggs are usually marketed to consumers as shelled eggs, but liquid egg products, such as liquid whole egg (LWE), liquid egg yolk and liquid egg white are generally preferred for industrial usage (De Jesús et al., 2013). Shelf life of these products can be prolonged by high hydrostatic pressure (HHP) treatment, which is a non-thermal technology (Tóth et al., 2017). LWE can be treated by a pressure of $350 \mathrm{MPa}$ for 5 minutes without significant changes in the viscosity (Monfort et al., 2012).

\section{Materials and methods}

Freshly produced salted $(0,6 \%)$ pasteurized $\left(66{ }^{\circ} \mathrm{C}, 5 \mathrm{~min}\right) \mathrm{LWE}$ was received from Capriovus Ltd. It was treated by high hydrostatic pressure of $350 \mathrm{MPa}$ for 5 minutes (RESATO FPU 100-200). Samples were subjected to a 4-week storage experiment. We defined total plate count and the number of Enterobacteriaceae with plate counting method ones a week. Samples were accepted if their total number of bacteria did not reach $10^{5} \mathrm{CFU} / \mathrm{g}$ and the number of Enterobacteriaceae was less than $10^{2} \mathrm{CFU} / \mathrm{g}$ according to european and hungarian regulations (Anonymous, 1998; Anonymous, 2005). Calorimetric properties of raw LWE and treated samples were examined by MicroDSC III instrument. Samples were heated up from $20^{\circ} \mathrm{C}$ to $95^{\circ} \mathrm{C}$ with a heating rate of $1.5^{\circ} \mathrm{C} / \mathrm{min}$, then cooled with a cooling rate of $3^{\circ} \mathrm{C} / \mathrm{min}$. Distilled water was used as reference material. Evaluation was carried out by Callisto Processing software. One-way ANOVA was performed by IBM SPSS Statistics 22.0 software $(\alpha=0,05)$.

\section{Results and discussion}

Total plate count and the number of Enterobacteriaceae are shown in Table 1. Salted and heat treated LWE is not accepted on day 21 of the storage experiment based on the total plate count and the number of Enterobacteriaceae according to the Hungarian regulations. With HHP treatment, the sample was accepted on day 21, but not on day 28.

Table 2 shows the calorimetric properties of salted, heat treated LWE with and without HHP treatment. We can compare data with raw whole eggs calorimetric properties. Their denaturation temperature is significantly different from raw eggs in both cases, but the entalphy of denaturation is just significantly different with HHP treatment. 
Table 1: Evolution of total plate count and Enterobacteriaceae during the storing experiment

\begin{tabular}{|c|c|c|c|c|c|c|c|c|}
\hline \multirow{3}{*}{ Sample } & \multicolumn{8}{|c|}{ Storage time (days) } \\
\hline & \multicolumn{2}{|c|}{7} & \multicolumn{2}{|c|}{14} & \multicolumn{2}{|c|}{21} & \multicolumn{2}{|c|}{28} \\
\hline & $\begin{array}{l}\log _{10} \\
\text { CFU }\end{array}$ & S.D. & $\begin{array}{l}\log _{10} \\
\text { CFU }\end{array}$ & S.D. & $\begin{array}{l}\log _{10} \\
\text { CFU }\end{array}$ & S.D. & $\begin{array}{l}\log _{10} \\
\text { CFU }\end{array}$ & S.D. \\
\hline \multicolumn{9}{|l|}{ Total plate count } \\
\hline LWE heat and salt & 2.99 & 0.24 & 4.26 & 0.23 & $5.08^{\mathrm{a}}$ & 0.06 & $5.92^{\mathrm{a}}$ & 0.23 \\
\hline LWE heat, salt and HHP & 1.97 & 0.11 & 3.15 & 0.08 & 4.34 & 0.07 & $5.28^{\mathrm{a}}$ & 0.17 \\
\hline \multicolumn{9}{|l|}{ Enterobacteriaceae } \\
\hline LWE heat and salt & $<1$ & - & $2.14 \mathrm{~b}$ & 0.12 & $2.71^{\mathrm{b}}$ & 0.11 & $3.32^{\mathrm{b}}$ & 0.06 \\
\hline LWE heat, salt and HHP & $<1$ & - & $<1$ & - & 1.15 & 0.19 & $2.30^{\mathrm{b}}$ & 0.05 \\
\hline
\end{tabular}

a: not accepted according to Anonymous, $2005\left(>10^{5}\right)$; b: not accepted according to Anonymous, $1998\left(>10^{2}\right)$

Table 2: Denaturation temperature and enthalpy of raw $\mathrm{LWE}$, heat treated $\left(66^{\circ} \mathrm{C}, 5 \mathrm{~min}\right)$ and salted $(0,6 \%)$ $\mathrm{LWE}$ and heat treated $\left(66^{\circ} \mathrm{C}, 5 \mathrm{~min}\right)$, HHP treated (350 MPa, $\left.5 \mathrm{~min}\right)$ and salted $(0,6 \%) \mathrm{LWE}$

\begin{tabular}{|l|c|c|c|c|}
\hline \multirow{2}{*}{ Sample } & \multicolumn{2}{|c|}{ Denaturation temperature $\left[{ }^{\circ} \mathrm{C}\right]$} & \multicolumn{2}{c|}{ Enthalpy of denaturation [J/g] } \\
\cline { 2 - 5 } & Mean & S.D. & Mean & S.D. \\
\hline Raw LWE & $75.44^{\mathrm{a}}$ & 0.083 & $1.786^{\mathrm{a}}$ & 0.073 \\
\hline Heat treatment+ salt & $77.41^{\mathrm{b}}$ & 0.029 & $1.774^{\mathrm{a}}$ & 0.032 \\
\hline Heat treatment + HHP + salt & $77.35^{\mathrm{b}}$ & 0.064 & $1.410^{\mathrm{b}}$ & 0.053 \\
\hline
\end{tabular}

a,b,c: means with different letter are significantly different $(\mathrm{P}<0.05)$

\section{Conclusion}

Our results show that HHP treatment of $350 \mathrm{MPa}$ for 5 minutes prolongs the shelf life of salted pasteurized LWE about a week, but it can cause changes in calorimetric properties. In our next study we examine the changes in technofunctional properties.

\section{Acknowledgement}

\section{\#.SUPported BY the ÚNKP-18-2 New National Excellence Program of THE Ministry OF Human CAPACITIEs" and Capriovus Ltd.}

\section{References}

Anonymous (1998): 4/1998. (XI. 11.) EüM rendelet az élelmiszerekben előforduló mikrobiológiai szennyeződések megengedhető mértékéről. <URL: http://net.jogtar.hu/jogszabaly?docid=99800004.EUM. Accessed 19 April 2018.

Anonymous (2005): COMMISSION REGULATION (EC) No 2073/2005 of 15 November 2005 (Text with EEA relevance). Official Journal of the European Union. L 338, 22.12.2005, pp. 1-26.

de Jesús, M.N., Zanqui, A.B., Valderrama, P., Tanamati, A., Maruyama, S.A., de Souza, N.E., Matsushita, M. (2013): Sensory and physico-chemical characteristics of desserts prepared with egg products processed by freeze and spray drying. Food Sci. Technol. 33: 3. 549-554. DOI: http://dx.doi.org/10.1590/S010120612013005000083

Monfort, S., Ramos, S., Meneses, N., Knorr, D., Raso, J., Álvarez, I. (2012): Design and evaluation of a high hydrostatic pressure combined process for pasteurization of liquid whole egg. Innovative Food Science \& Emerging Technologies. 14. 1-10. DOI: https://doi.org/10.1016/j.ifset.2012.01.004

Tóth, A., Németh, Cs, Horváth, F., Zeke, I., Friedrich, L. (2017): Impact of HHP on microbiota and rheological properties of liquid egg white, a kinetic study. Journal of Biotechnology. 256. 93. DOI: http://dx.doi. org/10.1016/j.jbiotec.2017.06.1119 